Trinity College

Trinity College Digital Repository

Faculty Scholarship

$10-2009$

\title{
Environmental Correlates of Breeding in the Crested Caracara (Caracara cheriway)
}

Joan L. Morrison

Trinity College, joan.morrison@trincoll.edu

Kyle E. Pias

Trinity College

Jonathan B. Cohen

Virginia Polytechnic Institute and State University

Daniel H. Catlin

Virginia Polytechnic Institute and State University

Follow this and additional works at: https://digitalrepository.trincoll.edu/facpub

Part of the Biology Commons 


\title{
ENVIRONMENTAL CORRELATES OF BREEDING IN THE CRESTED CARACARA (CARACARA CHERIWAY)
}

\author{
Joan L. Morrison, ${ }^{1,2,4}$ Kyle E. Pias, ${ }^{1,5}$ Jonathan B. Cohen, ${ }^{3}$ and Daniel H. Catlin ${ }^{3}$ \\ ${ }^{1}$ Department of Biology, Trinity College, 300 Summit Street, Hartford, Connecticut 06106, USA; \\ ${ }^{2}$ MacArthur Agro-Ecology Research Center, 300 Buck Island Ranch Road, Lake Placid, Florida 33852, USA; and \\ ${ }^{3}$ Department of Fisheries and Wildlife Science, Virginia Tech, 100 Cheatham Hall, Blacksburg, Virginia 24061, USA
}

\begin{abstract}
AвStrACt.-We evaluated the influence of weather on reproduction of the Crested Caracara (Caracara cheriway) in an agricultural landscape in south-central Florida. We used a mixed logistic-regression modeling approach within an information-theoretic framework to examine the influence of total rainfall, rainfall frequency, and temperature on the number of breeding pairs, timing of breeding, nest success, and productivity of Crested Caracaras during 1994-2000. The best models indicated an influence of rainfall frequency and laying period on reproduction. More individuals nested and more pairs nested earlier during years with more frequent rainfall in late summer and early fall. Pairs that nested later in each breeding season had smaller clutches, lower nest success and productivity, and higher probability of nest failure. More frequent rainfall during early spring months that are usually characterized by water deficit (March-May), more frequent rainfall during the fall drawdown period (September-November), and a shorter winter dry period showed some association with higher probability of brood reduction and lower nest success. The proportion of nests that failed was higher in "wet" years, when total rainfall during the breeding season (September-April) was $>10 \%$ above the 20-year average. Rainfall may influence reproduction in Crested Caracaras indirectly through food resources. As total rainfall increased during February-April, when most pairs are feeding nestlings or dependent fledglings, the proportion of drawdown-dependent species (those that become available as rainfall decreases and wetlands become isolated and shallow) in the diet of Crested Caracaras declined, which may indicate reduced availability of foraging habitat for this primarily terrestrial raptor. Received 22 September 2008, accepted 7 April 2009.
\end{abstract}

Key words: agriculture, Caracara cheriway, Crested Caracara, Florida, nest success, productivity, rainfall, raptor.

\section{Factores Ambientales Correlacionados con la Reproducción en Caracara cheriway}

RESUMEN.-Evaluamos la influencia del clima sobre la reproducción de Caracara cheriway en un paisaje agrícola en el centro-sur de Florida. Usamos una aproximación de selección de modelos con regresión logística mixta en el marco de la teoría de la información para examinar la influencia de la pluviosidad total, la frecuencia de lluvias y la temperatura sobre el número de parejas reproductivas, el momento en que sucede la reproducción, el éxito de anidación y la productividad de C. cheriway entre 1994 y 2000. Los mejores modelos indicaron una influencia de la frecuencia de lluvias y del periodo de puesta sobre la reproducción. Un mayor número de individuos y más parejas anidaron más temprano en los años con una mayor frecuencia de lluvias a fines del verano e inicios del otoño. Las parejas que anidaron más tarde en cada época reproductiva tuvieron puestas menores, menor éxito de anidación y productividad, y una mayor probabilidad de fracasar en un intento de anidación. Una mayor frecuencia de lluvias durante el inicio de la primavera, que está generalmente caracterizado por un déficit hídrico (marzo-mayo), una mayor frecuencia de lluvia en el otoño durante el periodo de vaciamiento de los cuerpos de agua (septiembre-noviembre), y un periodo seco más corto durante el invierno, mostraron una asociación con una mayor probabilidad de reducción de la nidada y menor éxito de anidación. La proporción de nidos que fracasaron fue mayor en los años más húmedos, cuando la cantidad de lluvia durante el periodo reproductivo (septiembre-abril) estuvo $>10 \%$ sobre el promedio de los últimos 20 años. La pluviosidad puede influenciar la reproducción de C. cheriway de manera indirecta a través de los recursos alimenticios. Con el aumento de la cantidad de lluvia total durante febrero a abril, cuando la mayoría de las parejas se encuentran alimentando a sus polluelos, la proporción de especies dependientes de los periodos de vaciamiento (aquellas que se hacen disponibles cuando la pluviosidad disminuye y los humedales se hacen más someros y aislados) en la dieta de C. cheriway disminuyó, lo que puede estar indicando una reducción en la disponibilidad de hábitat de forrajeo para esta especie de rapaz principalmente terrestre.

${ }^{4}$ E-mail: joan.morrison@trincoll.edu

${ }^{5}$ Present address: U.S. Geological Survey Fish and Wildlife Cooperative Research Unit, Newins-Ziegler Hall, University of Florida, Gainesville, Florida 32614, USA.

The Auk, Vol. 126, Number 4, pages 755-764. ISSN 0004-8038, electronic ISSN 1938-4254. @ 2009 by The American Ornithologists' Union. All rights reserved. Please direct all requests for permission to photocopy or reproduce article content through the University of California Press's Rights and Permissions website, http://www.ucpressjournals. com/reprintInfo.asp. DOI: 10.1525/auk.2009.08186 
BIRDS GENERALLY REPRODUCE when conditions are most favorable (Lack 1968), and weather is an important influence on reproductive performance and population dynamics. Many studies have documented a link between rainfall and breeding, and variability in precipitation may influence the proportion of a population breeding, breeding chronology, reproductive effort, and nest success of birds in both temperate and arid regions (Lloyd 1999, Whitehead and Saalfeld 2000, Chase et al. 2005).

Annual variation in rainfall may influence reproductive parameters through food-mediated processes both directly and indirectly, by affecting prey populations and foraging habitat, respectively (Boag and Grant 1984, Bildstein et al. 1990, Illera and Díaz 2006). For example, the timing of breeding and reproductive success of wading birds nesting in freshwater wetlands depend on present and past surface-water conditions because they influence the distribution and availability of prey (Ogden et al. 1980, Frederick and Collopy 1989, Cézilly et al. 1995). Rainfall can affect the foraging success of birds by altering the visibility (Grubb 1977) or behavior (Olsen and Olsen 1992, Gross and Price 2000) of prey. The influence of rainfall may also occur through interactions with predator-mediated processes (Rotenberry and Wiens 1989, Fletcher and Koford 2004) or density-dependence (Bennetts et al. 2000, Morrison and Bolger 2002).

Food and weather are primary factors limiting raptor populations (Newton 1979), and weather can affect breeding chronology and success primarily by influencing food supply (Kostrzewa and Kostrzewa 1991, Dawson and Bortolotti 2000, Keane at al. 2006). Adverse weather also can directly affect survival of adults and young (Kostrzewa and Kostrzewa 1990, Bradley et al. 1997). Interactions among environmental variables, for example precipitation and temperature, may influence the density of breeding pairs (Kostrzewa 1989, Rodríguez and Bustamante 2003), a species' primary prey (Gargett and Gargett 1995, Steenhoff et al. 1997), adults' hunting effort (Rijnsdorp et al. 1981), or provisioning rates (Redpath et al. 2002).

We studied the breeding biology of the Crested Caracara ( $\mathrm{Ca}$ racara cheriway; hereafter "caracara") in south-central Florida, where the species occurs as a relatively small and isolated population (Morrison 1996). It is the only species in the subgroup Caracarinae (family Falconidae) that occurs in North America, where it primarily inhabits open grassland and pasture habitats. The breeding biology and breeding-season diet have been described for populations in Texas (Dickinson and Arnold 1996), Baja California Sur, Mexico (Rivera-Rodríguez and Rodríguez-Estrella 1993, Rodríguez-Estrella and Rivera-Rodríguez 1997), and Florida (Morrison 1999, Morrison and Pias 2006), but little is known about influences of environmental factors on this species' life history. Here, we examine associations between environmental factors and the caracara's breeding biology, reproductive success, and vertebrate diet during the breeding period in Florida.

\section{Methods}

We studied caracara reproduction throughout a $21,000-\mathrm{km}^{2}$ area in south-central Florida that encompasses much of the species' currently known breeding range in the state (Morrison 1999). Habitats and patterns of land use have been described in detail by Morrison and Humphrey (2001). Caracaras breed throughout the region, and currently most breeding pairs are found on privately owned cattle ranches (Morrison and Humphrey 2001), where the landscape is dominated by "improved" pasture, in which the native ground and understory vegetation has been removed and replaced with exotic grass species managed intensively as forage for cattle. Pastures typically are laced with extensive networks of ditches, which promote drainage, and wetlands of varying sizes and hydrology that are flooded during the wet season but may become isolated and even dry out completely during the dry season (usually from October or November to May).

Southern Florida has a humid, subtropical climate with a distinct annual cycle of temperature and precipitation (Chen and Gerber 1990). During the rainy season (June-September), temperatures are warm and relatively uniform, averaging $\sim 28^{\circ} \mathrm{C}$. Convective rains and thunderstorms occur almost daily. From September through November, rainfall typically declines dramatically in total amount and frequency. During the dry season, temperatures are cooler but rarely drop below freezing and there is little rainfall.

Nest searching and monitoring.-From 1994 through 2000, we monitored caracara breeding areas (including nest sites and areas used for roosting and foraging) for breeding activity, defining "active" nests as those in which eggs were laid (Morrison 1999). As the study progressed, our access to parts of the study areaparticularly privately owned land-expanded, allowing us to monitor more breeding areas. From 1996 to 2000, we monitored 55 breeding areas each year.

We visited all nests approximately every other week to determine breeding chronology and nest status. We divided each month into two periods, the first (days 1-15) or second (days 16end) half of each month, and assigned initiation of each nest to one of these periods. On the basis of breeding chronology, we assigned the first half of September as the first laying period of the breeding season each year (Morrison 1999). To evaluate differences in initiation of breeding across years, we determined the percentage rank for each nest each year, according to laying period, defining "early-season" nests as those with a percentage rank of $0-25 \%$ and "late-season" nests as those with a percentage rank of 75-100\% (Morrison 1999). Early-season nests were not always initiated in the same laying period each year but were identified in relation to the pattern of breeding for the overall sample of nests, annually. We compared nest success between early- and late-season nests and among years using the program CONTRAST (Sauer and Williams 1989).

Reproductive performance.-For each nest, we determined clutch size and percent brood reduction (number of young successfully fledged per number of eggs laid) and calculated nest success, defined as the probability of a breeding attempt resulting in at least one young surviving to fledging, using the Mayfield method (Mayfield 1961, Johnson 1979). Because some pairs double brooded within the same breeding season or renested after failure (Morrison 1998, 1999) and second clutches may not be independent of first clutches, in this analysis we consider only "first" nests, either the first of two nests or a single nest (only one clutch produced per season; Morrison 1999). Annual productivity was defined as the number of young fledged during the first attempt by each breeding pair.

Environmental data.-We considered September-April to be the caracara's breeding season because most pairs initiated nests 
during these months each year. Using precipitation and temperature data collected at 35 weather stations across the study area (National Oceanic and Atmospheric Administration [NOAA] 2007, South Florida Water Management District 2007), we developed variables to be used in assessment of environmental factors that possibly influence the breeding biology and reproductive success of caracaras. Daily rainfall data from all stations were summed by month, then averaged to represent total monthly rainfall for the study area. We also determined the percent deviation of total monthly rainfall from monthly totals calculated for the 20-year period 1981-2000 (NOAA 2007), for each month of the study period. We classified each breeding season of the study as either "wet" or "dry" if total rainfall for September-April was $\geq 2 \times$ the standard error ( $10 \%)$ either above or below the 20 -year average, respectively, for this period. We also calculated rainfall frequency, the average percentage of days each month that the study area received essentially no $(\leq 2.5 \mathrm{~mm}$ total $)$ rainfall. Similarly, we determined average maximum and minimum temperatures for each month of the study period and used the percent deviation of these values from the respective 20-year averages as indices of extreme heat or cold.

We developed these environmental variables for the breeding season (September-April) and for all combinations of months we considered relevant to the caracara's breeding biology-for example, the wet season (June-August), onset of the dry season (September-October), dry season (December-May), early breeding season (September-December)_for 1994 through 2000.

Because of the seasonal pattern of wet and dry months, and because caracaras nested primarily during the dry winter months (Morrison 1999), we developed additional variables to describe the relative change in precipitation between the wet summer and the dry winter months and the overall duration of the winter dry period. First, we examined the potential influence on caracara breeding biology of drawdown, the seasonal decline in the amount and frequency of rainfall that typically occurs from September into November each year following the wet summer months (Fig. 1). We defined drawdown as occurring during the first month when total monthly rainfall was $\leq 50 \%$ of the total rainfall in the previous month (Chen and Gerber 1990). We described drawdown for each year using the overall percent reduction in total rainfall between September and November and the percent reduction in total rainfall during the month when drawdown first occurred (September, October, or November). We described the duration of the dry period following drawdown (dry period length) as the maximum number of consecutive weeks between November and April having daily rainfall averaging $\leq 2.5 \mathrm{~mm}$.

Vertebrate diet during the breeding season.-To assess the caracara's vertebrate diet during the breeding season, we collected prey remains from the base of the nest tree at active nest sites. For analysis of diet in relation to environmental parameters, we selected 86 prey remain samples such that sample sizes for February, March, and April of 1994-1997 were similar. Most pairs are feeding nestlings or dependent fledglings during these months, and these samples represented 40 different breeding areas, $30 \%$ of the known breeding areas of the species in Florida (Morrison and Humphrey 2001). Therefore, our sample provides a good representation of the vertebrates fed to caracara young in Florida during the late nestling-early fledgling period in those years.

Many of the caracara's vertebrate prey species inhabit wetlands (Morrison and Pias 2006), and we designated these species as "rainfall-influenced" or "drawdown-influenced" on the basis of their life histories. Rainfall-influenced prey, which include turtles,

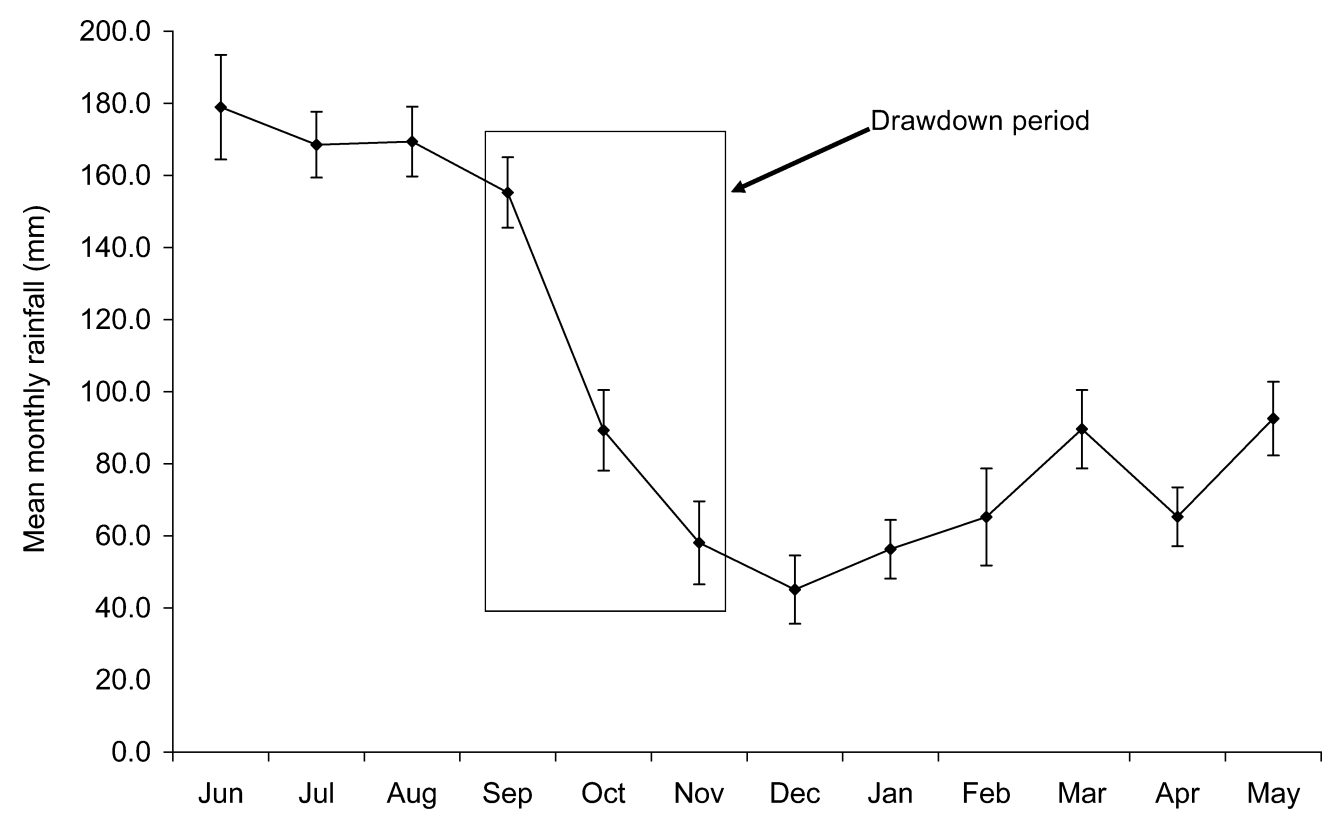

$1981-2000$

FIG. 1. Mean monthly total rainfall in south-central Florida over the 20-year period 1981-2000, indicating the period of drawdown. 
AuK, VOL. 126

snakes, sirens, and amphiumas, are cryptic or scarce during dry periods but begin dispersing across the landscape and breeding at the onset of increasing rainfall in the summer months. Drawdown-influenced prey, which include Walking Catfish (Clarias batrachus), Bowfin (Amia calva), and gar (Lepisosteidae), are unavailable during periods when water levels are high in wetlands and waterways across the landscape, but during drawdown they become concentrated in increasingly isolated and shallow wetlands and, thus, more available as prey (Batzer et al. 1999, Townsend et al. 2006).

We determined the proportion of rainfall-influenced and drawdown-influenced vertebrate prey items in the caracara's diet in February, March, and April 1994-1997, pooling monthly data among years. We used simple correlation to examine associations between these proportions and total rainfall in each month during this period.

Statistical analyses.-We used mixed logistic regression (Hosmer and Lemeshow 1989) to evaluate the effect of each weather variable on laying period (early $=1$, late $=0$ ), clutch size (clutch size of $3=1,<3=0)$, and nest success ( $1=$ successful, $0=$ failed), with a random year effect to control for possible non-independence of observations within years due to unmeasured variables. We used mixed multinomial logistic regression (McFadden 1974) to evaluate the effects of weather on percent brood reduction (possible values $=0,0.33,0.5,0.67,1.0)$ and number of chicks fledged, and Poisson regression (McCullagh and Nelder 1989) to evaluate effects of weather on the number of active nests in 55 breeding areas monitored annually during 1996-2000. Because many of the explanatory variables were correlated, we ran models with one weather variable at a time (as well as an intercept-only "null" model).

Model selection for all tests was based on Akaike's information criterion corrected for small sample sizes (AIC ; A kaike 1973, Burnham and Anderson 2002). All statistical analyses were conducted using SAS/STAT, version 9.1.3 (SAS Institute, Cary, North Carolina), and SYSTAT, version 8.0 (SPSS, Chicago, Illinois), and the level of significance was set at $\alpha=0.05$. Results are reported as means \pm 2 SE unless otherwise indicated.

\section{Results}

Breeding chronology and reproductive success.-Overall, we identified 314 active nests (Table 1). Most pairs initiated egg laying in January each year, and the median egg-laying period did not differ among years (Kruskal-Wallis test, $H=5.90, \mathrm{df}=6, P=0.43$; Table 1 ). We also did not detect a difference among years for either clutch size (mean $2.28 \pm 0.08$ eggs; ANOVA, $F=1.42$, df $=6, P=0.21, n=$ 153 nests with known clutch size) or productivity (mean $1.60 \pm 0.10$ fledges; $F=1.18 \mathrm{df}=6, P=0.32$ ). Nest success varied among years $\left(\chi^{2}=287.97, \mathrm{df}=6, P<0.01\right.$; Table 1), being lower in 1995 and 1998 than in other years (pairwise comparisons in CONTRAST, $P<$ 0.01 ). Nest success was higher for early-season nests (mean $\pm \mathrm{SD}=$ $0.93 \pm<0.01, n=169$ ) than for late-season nests (mean $\pm \mathrm{SD}=0.79 \pm$ $<0.00, n=145, \chi^{2}=272.49, \mathrm{df}=6, P<0.01$ ). More nests suffered $\geq 50 \%$ brood reduction and failed in 1995 and 1998 (Table 1) than in other years; generally, if nests suffered as much as $50 \%$ brood reduction, they failed completely.

Rainfall and reproduction.-The best models indicated an influence of laying period and rainfall frequency on caracara

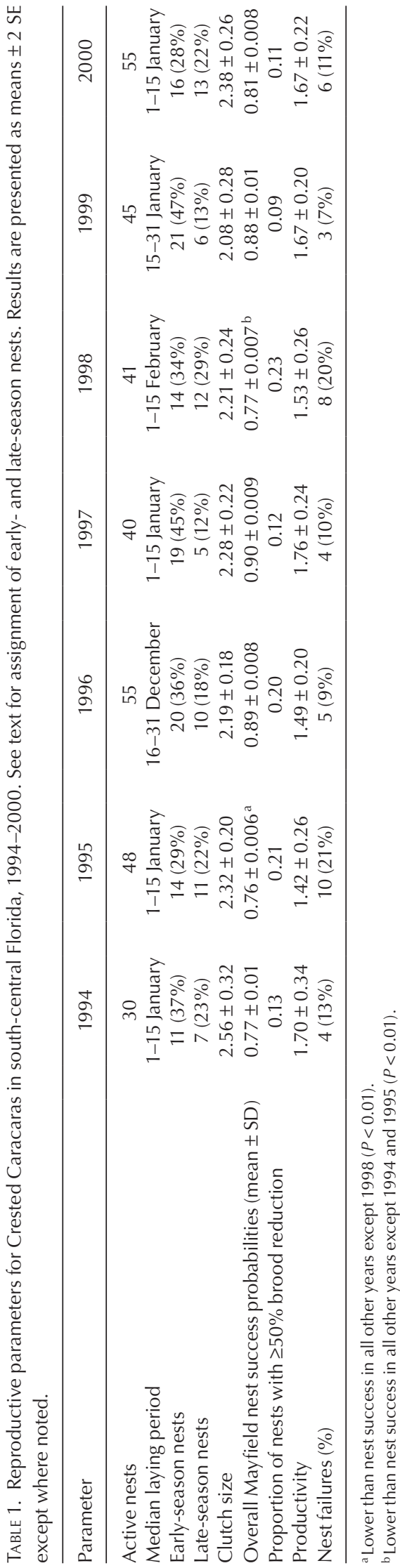


TABLE 2. Selection results for models explaining variation in reproductive parameters of Crested Caracaras in south-central Florida, 1994-2000. Sample size is 314 active nests unless otherwise noted. Models were evaluated using Akaike's information criterion corrected for small sample size $\left(\mathrm{AIC}_{\mathrm{c}}\right)$, likelihood, difference in $\mathrm{AIC}_{\mathrm{c}}$ from the top model $\left(\triangle \mathrm{AIC} \mathrm{C}_{\mathrm{c}}\right.$, and model weight $\left(w_{i}\right)$. All models with likelihood $>0.125$ for each reproductive parameter are presented (Burnham and Anderson 2002). If only one model is shown, the next best models in all cases were $>4 \mathrm{AIC}_{\mathrm{c}}$ units from the top model.

\begin{tabular}{|c|c|c|c|}
\hline Model & Likelihood & $\Delta \mathrm{AIC}_{\mathrm{c}}$ & $\mathrm{w}_{i}$ \\
\hline \multicolumn{4}{|l|}{ Laying period } \\
\hline $\begin{array}{l}\text { Frequency of rainfall } \\
\text { September- October }\end{array}$ & 1 & 0 & 0.29 \\
\hline $\begin{array}{l}\text { Frequency of rainfall August- } \\
\text { October }\end{array}$ & 0.56 & 1.15 & 0.16 \\
\hline Minimum January temperature & 0.48 & 1.52 & 0.14 \\
\hline $\begin{array}{l}\text { Frequency of rainfall October- } \\
\text { November }\end{array}$ & 0.31 & 2.32 & 0.09 \\
\hline Total rainfall August-October & 0.30 & 2.44 & 0.09 \\
\hline Total rainfall June-October & 0.17 & 3.55 & 0.05 \\
\hline \multicolumn{4}{|l|}{$\begin{array}{l}\text { Clutch size ( } n=153 \text { nests with } \\
\text { known clutch size) }\end{array}$} \\
\hline Laying period & 1 & 0 & 0.99 \\
\hline \multicolumn{4}{|l|}{ Brood reduction } \\
\hline Frequency of rainfall March-May & 1 & 0 & 0.22 \\
\hline Frequency of rainfall April-May & 0.93 & 0.14 & 0.20 \\
\hline Laying period & 0.84 & 0.35 & 0.18 \\
\hline \multicolumn{4}{|l|}{ Nest success } \\
\hline Laying period & 1 & 0 & 0.99 \\
\hline \multicolumn{4}{|l|}{$\begin{array}{l}\text { Annual productivity (number } \\
\text { fledged per breeding attempt) }\end{array}$} \\
\hline Laying period & 1 & 0 & 0.99 \\
\hline \multicolumn{4}{|l|}{$\begin{array}{l}\text { Number of nests ( } n=55 \text { breeding } \\
\text { areas monitored 1996-2000) }\end{array}$} \\
\hline $\begin{array}{l}\text { Frequency of rainfall August- } \\
\text { October }\end{array}$ & 1 & 0 & 0.96 \\
\hline
\end{tabular}

reproduction (Table 2). In years when it rained more often in late summer and early fall, more pairs nested (in 55 breeding areas monitored annually during 1996-2000) and more pairs nested earlier (Table 3). Pairs breeding late in the season were more likely to have smaller clutches, lower probability of a successful nest, lower productivity, and higher probability of total nest failure (Table 3). The proportion of failed nests generally tracked the percent deviation from the 20-year average rainfall during the breeding season (September-April), with a higher proportion of nests failing in "wet" years, $(\rho=0.86, P=0.01$; Fig. 2$)$. Although not highly weighted in model results because of the dominant effect of laying period, more total rainfall between September and November (less drawdown) was significantly associated with lower nest success (parameter estimate $-5.42 \pm 3.94, t=-2.74, P<0.01$ ). In addition, higher probability of $50 \%$ brood reduction and, thus, total nest failure was negatively associated with length of the dry period ( $\rho=-0.90, P=0.01$; Fig. 3 ), particularly with more rainfall occurring in March-May (Tables 2 and 3), months when most nests are in either the late nestling or the early fledgling stage.

Breeding-season vertebrate diet.-Analysis of vertebrate prey in the caracara's breeding-season diet suggests that as rainfall increased during February-April in 1994-1997, the proportion of drawdown-influenced prey in the diet declined (Fig. 4), though the association was not significant $(\rho=-0.86, P=0.36)$. There was no apparent association between the proportion of rainfallinfluenced items in the diet and increasing rainfall during these months.

\section{Discussion}

Weather has been implicated as a factor influencing the occurrence, timing, and success of breeding in many avian species, including raptors (Newton and Marquiss 1976, Kostrzewa and Kostrzewa 1991, Steenhof et al. 1997). On the basis of data from only three breeding seasons and the finding that egg laying by many caracara pairs occurred after the decline in precipitation in the fall each year, Morrison (1999) proposed a link between timing of the caracara's breeding season and the rainfall cycle in Florida. Data from seven breeding seasons further support this hypothesis, although current results suggest that the amount and frequency of pre-breeding-season rainfall may be more important than drawdown as an influence on the number of pairs laying eggs and the timing of egg laying. Therefore, the laying period apparently has the strongest influence on subsequent reproductive outcomes. Caracaras that initiated nests earlier in the breeding season had larger clutch sizes, reduced likelihood of brood reduction, and higher nest success and productivity.

TABLE 3. Parameter estimates for variables explaining Crested Caracara reproductive parameters, from the top models for each parameter (Table 2).

\begin{tabular}{|c|c|c|c|c|}
\hline Reproductive parameter & Explanatory variable & Estimate \pm SE & $t$ & $P$ \\
\hline \multirow[t]{3}{*}{ Laying period } & Frequency of rainfall September-October & $-20.32 \pm 4.49$ & -4.53 & $<0.01$ \\
\hline & Frequency of rainfall August-October & $-15.99 \pm 5.31$ & -3.01 & $<0.01$ \\
\hline & Minimum January temperature & $0.40 \pm 0.09$ & 4.3 & $<0.01$ \\
\hline Clutch size & Laying period & $-0.48 \pm 0.121$ & -4.47 & $<0.01$ \\
\hline \multirow[t]{2}{*}{ Probability of $\geq 50 \%$ brood reduction } & Frequency of rainfall March-May & $23.95 \pm 7.36$ & 3.25 & 0.02 \\
\hline & Frequency of rainfall April-May & $28.61 \pm 9.74$ & 2.94 & 0.03 \\
\hline Probability of $100 \%$ brood reduction & Laying period & $0.39 \pm 0.11$ & 3.40 & 0.01 \\
\hline Nest success & Laying period & $-0.48 \pm 0.09$ & -5.2 & $<0.01$ \\
\hline Probability of 1 rather than 0 fledges & Laying period & $-0.50 \pm 0.10$ & -4.82 & $<0.01$ \\
\hline Probability of 2 rather than 0 fledges & Laying period & $-0.45 \pm 0.09$ & -4.84 & $<0.01$ \\
\hline Probability of 3 rather than 0 fledges & Laying period & $-0.65 \pm 0.13$ & -4.98 & $<0.01$ \\
\hline Number of nests & Frequency of rainfall August-October & $3.33 \pm 0.35$ & 9.45 & $<0.01$ \\
\hline
\end{tabular}




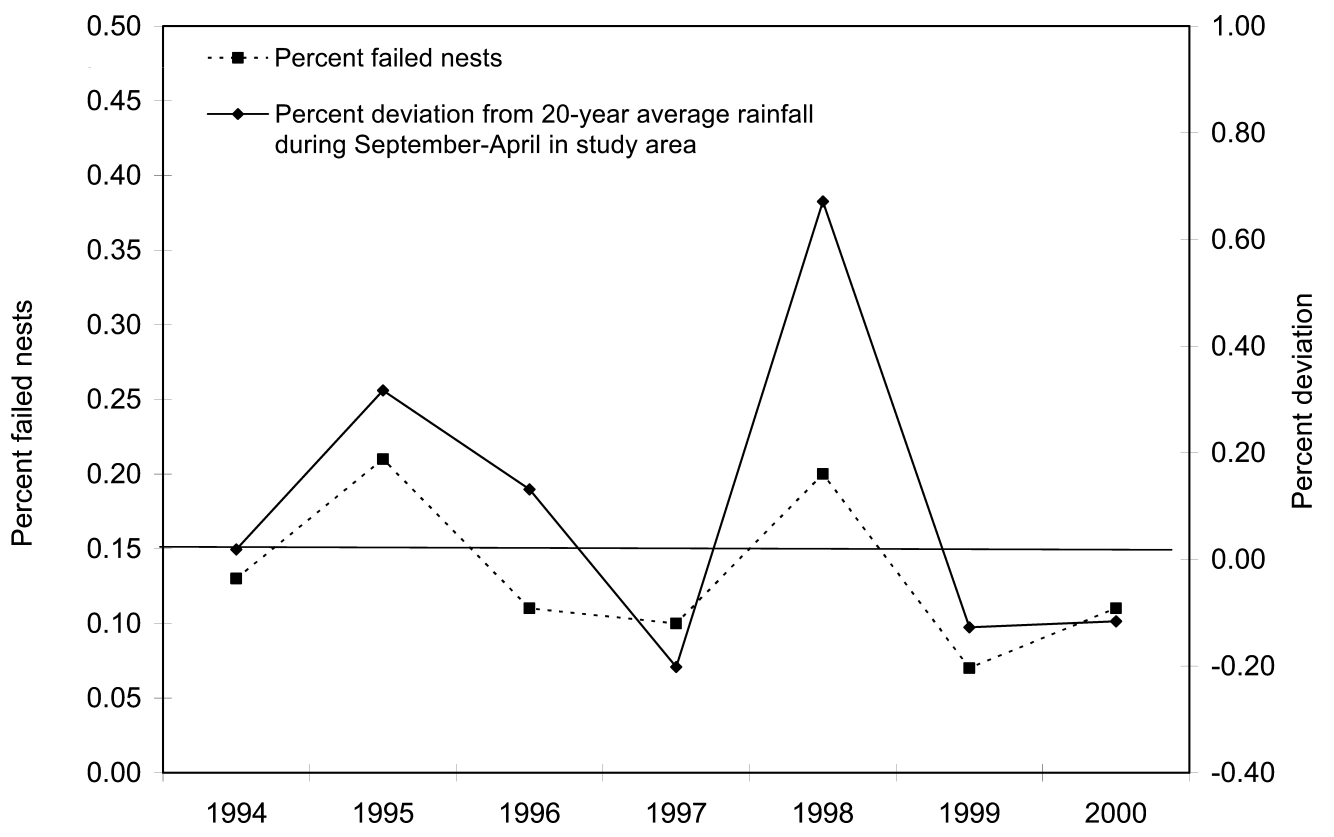

FIG. 2. A greater proportion of nests failed during "wet" years, when total rainfall during the breeding season (September-April) was $\geq 10 \%$ above the 20-year average.

Relationships between rainfall and caracara breeding are undoubtedly more complex, however, because results also indicate that patterns of rainfall throughout the annual cycle, particularly timing and frequency of precipitation, continue to influence annual reproductive outcomes. Rainfall occurring in early spring months that are usually characterized by water deficit (MarchMay) seems to be important; more frequent rainfall during these months and a shorter winter dry period showed some association with higher probability of brood reduction and total nest failure. Overall, a higher proportion of nests failed during years in which

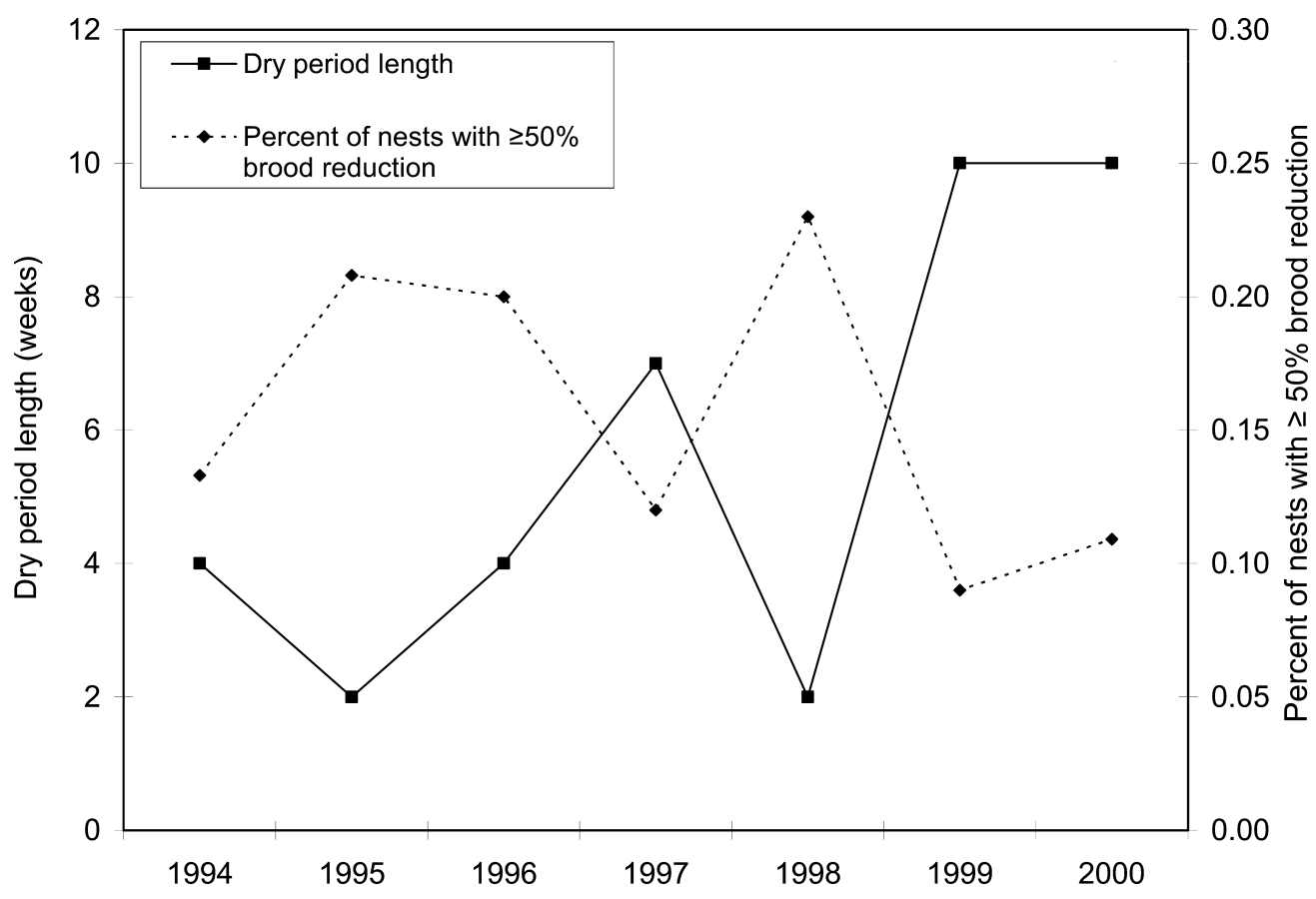

FIG. 3. A greater proportion of nests suffered $\geq 50 \%$ brood reduction during years with a shorter dry period, as measured by the number of consecutive weeks between November and April that had daily rainfall averaging $\leq 2.5 \mathrm{~mm}$. 


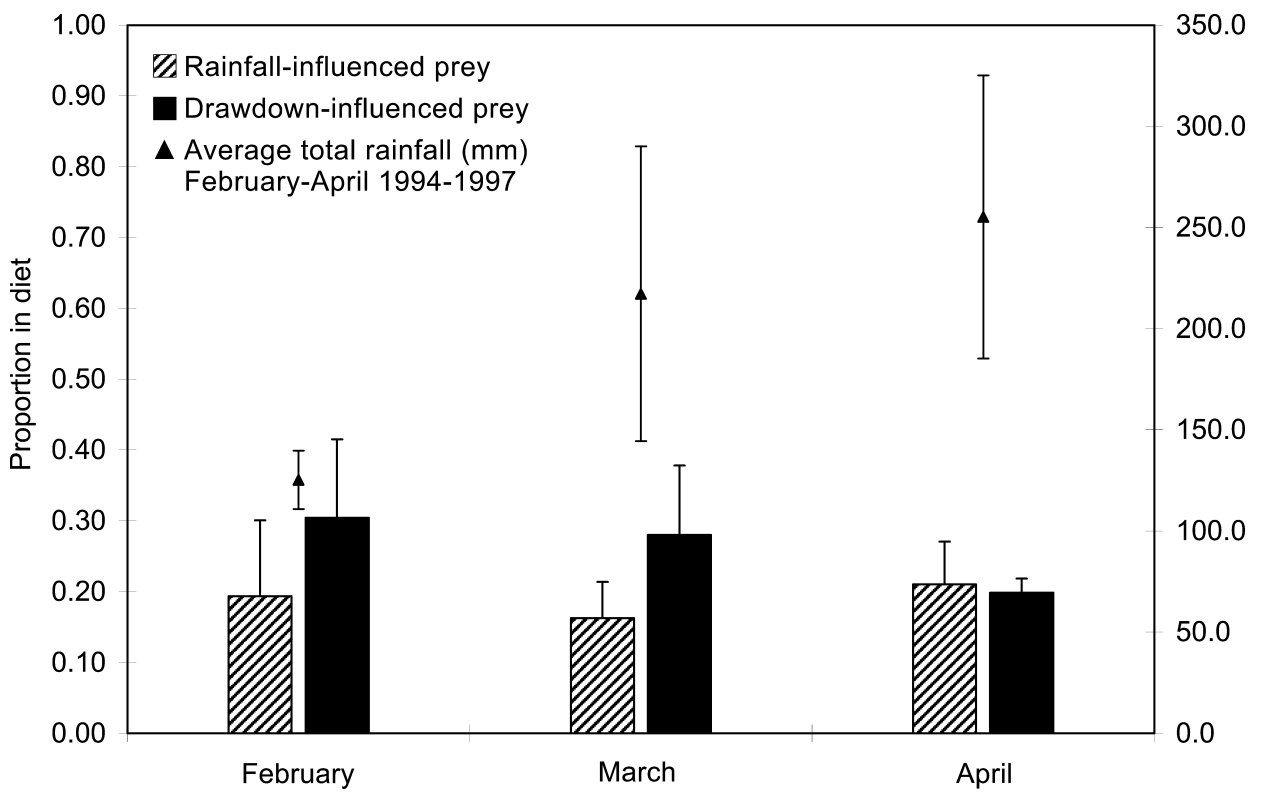

FIG. 4. As rainfall increased during February-April in 1994-1997, the proportion of drawdown-influenced prey species declined in the diet and the proportion of rainfall-influenced prey was similar.

total breeding-season rainfall was considerably higher than the 20-year average.

Weather may influence avian reproduction by influencing the food supply either directly, by affecting prey populations, or indirectly, by effects on foraging habitat. In tropical and subtropical regions, the abundance of food resources and, for some species, availability of foraging habitat are closely tied to rainfall cycles (Skutch 1950, Newton 1979). In Florida, the influence of water levels on food resources has been suggested as an important factor affecting timing of breeding and reproductive success in wading birds and other species (Kushlan et al.1975, Ogden et al 1980, Frederick and Collopy 1989, Morrison et al. 2007). Our findings are useful for generating hypotheses about how the amount and timing of rainfall in south-central Florida might influence the caracara's breeding biology. The onset of summer rains coincides with reproduction in several species of anurans (Meshaka 1997, Babbitt and Tanner 2000); thus, the amount and frequency of summer rainfall may provide a cue to a broad prey base available early in the caracara's breeding cycle. Seasonal availability and predictability of food may enhance individual females' ability to attain body condition necessary for breeding. During drought years, almost no amphibian breeding occurs in south Florida (Babbitt and Tanner 2000), and this perhaps results in fewer food resources for predators and delayed or missed breeding opportunities (Frederick and Collopy 1989). On the other hand, summer precipitation may predict future conditions for rearing young, which may be more important for timing successful reproduction (Eeva et al. 2000, Preston and Rotenberry 2006). Breeding caracaras feed on a wide variety of vertebrate and invertebrate prey (Morrison and Pias 2006), and late summer rainfall may provide a cue to breeding-season abundance of these prey species.

Patterns of rainfall during the summer and the subsequent winter dry months may influence the availability of foraging habitat throughout the caracara's breeding season. Wetland hydroperiod affects the distribution of amphibians, fish, and other prey in this region of Florida (Babbitt and Tanner 2000, Babbitt et al. 2003). During the fall drawdown period, these prey become concentrated in ephemeral wetlands, ponds, and ditches, and their availability to foraging wading birds increases (Kushlan et al. 1975, Ogden et al. 1980, Batzer et al. 1999). Caracaras regularly forage in these habitats, feeding on fish, amphibians, and reptiles (Morrison and Pias 2006) and kleptoparasitize wading birds that feed there (Rodríguez-Estrella and Rivera-Rodríguez 1992, J. L. Morrison pers. obs.). Unlike many raptors, caracaras are quite terrestrial and spend much of their foraging time walking about on the ground capturing insects and a variety of vertebrate prey (Morrison and Pias 2006, Morrison et al. 2008). Higher and more frequent rainfall during the normally dry winter months in south-central Florida may result in reduced availability of foraging habitat for caracaras. Annual variation in availability of foraging habitat and food during the winter dry period may influence reproductive success by affecting rates of brood reduction and nest failure, particularly if higher rainfall occurs in the months when parents are feeding large nestlings or dependent fledglings (February-April). Our finding that more nests failed in "wetter" years supports this idea.

Weather may also influence avian reproduction by directly affecting survival of adults and young (Adamcik et al. 1979, Kostrzewa and Kostrzewa 1990, Bradley et al. 1997). Although the winter climate in south-central Florida is generally mild, severe storms and cold fronts often pass through the region. Higher and more frequent rainfall during the normally dry winter months could lead directly to nestling mortality and consequent nest failure in Florida's caracara population.

Our analyses showed no difference in laying period, clutch size, and productivity among years-although, in fact, we recorded considerable within-year variation in these parameters. 
Rainfall varies both spatially and temporally across the study area; thus, our use of average values for these parameters likely obscures actual spatial and temporal variation in reproduction across the population. Laying period may explain much of the observed variation in clutch size and productivity among years, but other factors may also be important, such as variability in food resources or a number of causes of loss of eggs and chicks, any of which may be influenced by rainfall.

Our results are somewhat ambiguous in that most models implicated rainfall frequency (percentage of rainless days), rather than total rainfall, as having an influence on caracara breeding biology. However, for the period 1981-2000 we found a positive association between the percentage of days with $\geq 2.5 \mathrm{~mm}$ rainfall and total rainfall during September-October $\left(\rho=0.88, r^{2}=\right.$ $0.75, P=0.01)$ and during March-May $\left(\rho=0.84, r^{2}=0.71, P=0.02\right)$; when it rained more often, total rainfall was higher. Rainfall frequency has been associated with density of breeding pairs and reproductive success in other raptors (Adamcik et al. 1979, Gende et al. 1997, Morrison et al. 2007). Continued study over additional years might further elucidate observed patterns and possible associations between rainfall and reproduction in Florida's caracara population.

\section{ACKNOWLEDGMENTS}

We sincerely thank the landowners throughout south-central Florida who so generously provided access to their lands. We are grateful to S. McGehee, V. Dreitz, D. Todd, L. Phillips, and J. Arnett for their excellent assistance in the field, particularly with nest finding. W. Meshaka, K. Babbitt, and R. Franz enlightened our thoughts about the influence of rainfall on herpetofauna and raptor reproduction in the region. Funding was provided by the Avon Park Air Force Range, the Nongame Wildlife Program of the Florida Fish and Wildlife Conservation Commission, and the South Florida Water Management District, and we are grateful for assistance and support from personnel at these organizations and from the U.S. Fish and Wildlife Service, Vero Beach, Florida. We are especially indebted to personnel at the MacArthur AgroEcology Research Center and Archbold Biological Station, particularly J. Fitzpatrick, H. Swain, P. Bohlen, M. Deyrup, G. Lollis, and G. T. Bancroft for their cooperation and logistical support. Finally, thanks to the Department of Wildlife Ecology and Conservation of the Institute of Food and Agricultural Sciences, University of Florida, for providing additional funding and logistical support. This manuscript benefited from comments by $\mathrm{M}$. Bechard and two anonymous reviewers. This is contribution no. 125 from the MacArthur Agro-Ecology Research Center of Archbold Biological Station, Lake Placid, Florida.

\section{Literature Cited}

AdamciK, R. S., A. W. TodD, And L. B. KeIth. 1979. Demographic and dietary responses of Red-tailed Hawks during a snowshoe hare fluctuation. Canadian Field-Naturalist 93:16-27.

AкAIKE, H. 1973. Information theory and an extension of the maximum likelihood principle. Pages 267-281 in Second International Symposium on Information Theory (B. N. Petrov and F. Csáki, Eds.). Akademiai Kiadó, Budapest.
Babbitt, K. J., M. J. Baber, And T. L. TARR. 2003. Patterns of larval amphibian distribution along a wetland hydroperiod gradient. Canadian Journal of Zoology 81:1539-1552.

BABBitT, K. J., AND G. W. TANNER. 2000. Use of temporary wetlands by anurans in a hydrologically modified landscape. Wetlands 20:313-322.

Batzer, D. P., A. S. Shurtleff, and J. R. Robinette. 1999. Managing fish and invertebrate resources in a Wood Stork feeding pond. Journal of Freshwater Ecology 14:159-165.

Bennetts, R. E., M. Fasola, H. Hafner, And Y. Kayser. 2000. Influence of environmental and density-dependent factors on reproduction of Little Egrets. Auk 117:634-639.

Bildstein, K. L., W. Post, J. Johnston, And P. Frederick. 1990. Freshwater wetlands, rainfall, and the breeding ecology of White Ibises in coastal South Carolina. Wilson Bulletin 102:84-98.

BoAG, P. T., AND P. R. Grant. 1984. Darwin's finches (Geospiza) on Isla Daphne Major, Galapagos: Breeding and feeding ecology in a climatically variable environment. Ecological Monographs 54:463-489.

Bradley, M., R. Johnstone, G. Court, and T. Duncan. 1997. Influence of weather on breeding success of Peregrine Falcons in the Arctic. Auk 114:786-791.

Burnham, K. P., and D. R. Anderson. 2002. Model Selection and Multimodel Inference: A Practical Information-theoretic Approach. Springer-Verlag, New York.

Cézilly, F., V. Boy, R. E. Green, G. J. M. Hirons, And A. R. JohnSON. 1995. Interannual variation in Greater Flamingo breeding success in relation to water levels. Ecology 76:20-26.

Chase, M. K., N. Nur, AND G. R. Geupel. 2005. Effects of weather and population density on reproductive success and population dynamics in a Song Sparrow (Melospiza melodia) population: A long-term study. Auk 122:571-592.

Chen, E., And J. F. Gerber. 1990. Climate. Pages 11-34 in Ecosystems of Florida (R. L. Myers and J. J. Ewel, Eds.). University of Central Florida Press, Orlando.

Dawson, R. D., AND G. R. BoRTOLOTti. 2000. Reproductive success of American Kestrels: The role of prey abundance and weather. Condor 102:814-822.

DiCKINSON, V. M., AND K. A. ARnOLD. 1996. Breeding biology of the Crested Caracara in south Texas. Wilson Bulletin 108:516-523.

Eeva, T., S. Veistola, and E. Lehikoinen. 2000. Timing of breeding in subarctic passerines in relation to food availability. Canadian Journal of Zoology 78:67-78.

Fletcher, R. J., JR., AND R. R. Koford. 2004. Consequences of rainfall variation for breeding wetland blackbirds. Canadian Journal of Zoology 82:1316-1325.

Frederick, P. C., AND M. W. Collopy. 1989. Nesting success of five ciconiiform species in relation to water conditions in the Florida Everglades. Auk 106:625-634.

Gargett, V., And E. Gargett. 1995. The influence of rainfall on Black Eagle breeding over 31 years in the Matobo Hills, Zimbabwe. Ostrich 66:114-121.

Gende, S. M., M. F. Willson, And M. Jacobsen. 1997. Reproductive success of Bald Eagles (Haliaeetus leucocephalus) and its association with habitat or landscape features and weather in southeast Alaska. Canadian Journal of Zoology 75:1595-1604.

Gross, S. J., AND T. D. PriCE. 2000. Determinants of the northern and southern range limits of a warbler. Journal of Biogeography 27:869-878. 
GRUBb, T. G., JR. 1977. Weather-dependent foraging in Ospreys. Auk 94:146-149.

Hosmer, D. W., And S. Lemeshow. 1989. Applied Logistic Regression. Wiley, New York.

Illera, J. C., AND M. DíAz. 2006. Reproduction in an endemic bird of a semiarid island: A food-mediated process. Journal of Avian Biology 37:447-456.

JoHnson, D. H. 1979. Estimating nest success: The Mayfield method and an alternative. Auk 96:651-661.

Keane, J. J., M. L. Morrison, And D. M. Fry. 2006. Prey and weather factors associated with temporal variation in Northern Goshawk reproduction in the Sierra Nevada, California. Pages 85-99 in The Northern Goshawk: A Technical Assessment of Its Status, Ecology, and Management (M. L. Morrison, Ed.). Studies in Avian Biology, no. 31.

Kostrzewa, A. 1989. The effect of weather on density and reproductive success in Honey Buzzards Pernis apivorus. Pages 187191 in Raptors in the Modern World: Proceedings of the III World Conference on Birds of Prey and Owls, Eilat, Israel (B.-U. Meyburg and R. D. Chancellor, Eds.). World Working Group on Birds of Prey, Berlin.

Kostrzewa, A., And R. Kostrzewa. 1990. The relationship of spring and summer weather with density and breeding performance of the buzzard Buteo buteo, goshawk Accipiter gentilis and kestrel Falco tinnunculus. Ibis 132:550-559.

Kostrzewa, R., And A. Kostrzewa. 1991. Winter weather, spring and summer density, and subsequent breeding success of Eurasian Kestrels, Common Buzzards and Northern Goshawks. Auk 108:342-347.

Kushlan, J. A., J. C. Ogden, And A. L. Higer. 1975. Relation of water level and fish availability to Wood Stork reproduction in the southern Everglades, Florida. Open File Report 75-434. U.S. Geological Survey, Tallahassee, Florida.

LACK, D. 1968. Ecological Adaptations for Breeding in Birds. Methuen, London.

LlOYD, P. 1999. Rainfall as a breeding stimulus and clutch size determinant in South African arid-zone birds. Ibis 141:637-643.

MAYFiELD, H. [F.] 1961. Nesting success calculated from exposure. Wilson Bulletin 73:255-261.

McCullagh, P., ANd J. A. Nelder. 1989. Generalized Linear Models, 2nd ed. Chapman \& Hall, London.

McFadden, D. 1974. Conditional Logit Analysis of Qualitative Choice Behavior. Pages 105-142 in Frontiers in Econometrics (P. Zarembka, Ed.). Academic Press, New York.

MeshaKA, W. E., JR. 1997. The herpetofauna of Buck Island Ranch: An altered wetland in south-central Florida. Florida Scientist 60:1-7.

Morrison, J. L. 1996. Crested Caracara (Caracara plancus). In The Birds of North America, no. 249 (A. Poole and F. Gill, Eds.). Academy of Natural Sciences, Philadelphia, and American Ornithologists' Union, Washington, D.C.

MORRISON, J. L. 1998. Effects of double brooding on productivity of Crested Caracaras. Auk 115:979-987.

MORRISON, J. L. 1999. Breeding biology and productivity of Florida's Crested Caracaras. Condor 101:505-517.

Morrison, J. L., And S. R. Humphrey. 2001. Conservation value of private lands for Crested Caracaras in Florida. Conservation Biology 15:675-684.
Morrison, J. L., M. McMillian, J. B. Cohen, and D. H. CatLIN. 2007. Environmental correlates of nesting success in Redshouldered Hawks. Condor 109:648-657.

Morrison, J. L., AND K. E. Pias. 2006. Assessing the vertebrate component of the diet of Florida's Crested Caracaras. Florida Scientist 69:36-43.

Morrison, J. L., K. E. Pias, J. Abrams, I. G. W. Gottlieb, M. DeYrup, AND M. MCMillian. 2008. Invertebrate diet of breeding and non-breeding Crested Caracaras (Caracara cheriway) in Florida. Journal of Raptor Research 42:38-47.

Morrison, S. A., AND D. T. Bolger. 2002. Variation in a sparrow's reproductive success with rainfall: Food and predator-mediated processes. Oecologia 133:315-324.

National Oceanic and Atmospheric Administration. 2007. Climate Data Inventories. [Online.] U.S. Department of Commerce, National Climatic Data Center. Available at http://www. ncdc.noaa.gov/oa/climate/climateinventories.html.

Newton, I. 1979. Population Ecology of Raptors. Buteo Books, Vermillion, South Dakota.

Newton, I., And M. Marquiss. 1976. Occupancy and success of nesting territories in the European Sparrowhawk. Raptor Research 10:65-71.

Ogden, J. C., H. W. Kale II, and S. A. Nesbitt. 1980. The influence of annual variation in rainfall and water levels on nesting by Florida populations of wading birds. Transactions of the Linnaean Society of New York 9:115-126.

Olsen, P., AND J. OlsEN. 1992. Does rain hamper hunting by breeding raptors? Emu 92:184-187.

Preston, K. L., And J. T. Rotenberry. 2006. The role of food, nest predation, and climate in timing of Wrentit reproductive activities. Condor 108:832-841.

Redpath, S. M., B. E. Arroyo, B. Etheridge, F. Leckie, K. BouwMAN, AND S. J. Thirgood. 2002. Temperature and Hen Harrier productivity: From local mechanisms to geographical patterns. Ecography 25:533-540.

Rijnsdorp, A., S. DaAn, and C. Dijkstra. 1981. Hunting in the kestrel, Falco tinnunculus, and the adaptive significance of daily habits. Oecologia 50:391-406.

Rivera-Rodríguez, L. B., ANd R. Rodríguez-Estrella. 1993. Breeding ecology of the Crested Caracara (Polyborus plancus) in the Cape region, Baja California Sur, Mexico. Journal of Raptor Research 27:91-92.

Rodríguez, C., AND J. Bustamante. 2003. The effect of weather on Lesser Kestrel breeding success: Can climate change explain historical population declines? Journal of Animal Ecology 72:793-810.

Rodríguez-Estrella, R., AND L. Rivera-Rodríguez. 1992. Kleptoparasitism and other interactions of Crested Caracara in the Cape region, Baja California, Mexico. Journal of Field Ornithology 63:177-180.

Rodríguez-Estrella, R., And L. B. Rivera-Rodríguez. 1997. Crested Caracara food habits in the Cape region of Baja California, Mexico. Journal of Raptor Research 31:228-233.

Rotenberry, J. T., AND J. A. Wiens. 1989. Reproductive biology of shrubsteppe passerine birds: Geographical and temporal variation in clutch size, brood size, and fledging success. Condor 91:1-14.

Sauer, J. R., AND B. K. Williams. 1989. Generalized procedures for testing hypotheses about survival or recovery rates. Journal of Wildlife Management 53:137-142. 
Skutch, A. F. 1950. The nesting seasons of Central American birds in relation to climate and food supply. Ibis 92:185222.

South Florida Water Management District. 2007. DBHYDRO browser, environmental monitoring. [Online.] Available at www.sfwmd.gov/portal/page?_pageid=2235,4688582\&_ dad=portal\&_schema=PORTAL.

Steenhof, K., M. N. Kochert, and T. L. McDonald. 1997. Interactive effects of prey and weather on Golden Eagle reproduction. Journal of Animal Ecology 66:350-362.
Townsend, S. E., E. V. Pearlstine, F. J. Mazzotti, and C. W. DEREN. 2006. Wading birds, shorebirds, and waterfowl in rice fields within the Everglades Agricultural Area. Florida Field Naturalist 34:9-20.

Whitehead, P. J., And K. SaAlfeld. 2000. Nesting phenology of Magpie Geese (Anseranas semipalmata) in monsoonal northern Australia: Responses to antecedent rainfall. Journal of Zoology (London) 251:495-508.

Associate Editor: M. Bechard 